\title{
Pengaruh Insentif dan Lingkungan Kerja Terhadap Semangat Kerja Pegawai pada Biro Administrasi Umum Universitas Islam Negeri (UIN) Sultan Syarif Kasim Riau
}

\author{
Suparjono \\ Universitas Islam Negeri (UIN) Sultan Syarif Kasim Riau, Pekanbaru, Indonesia
}

\begin{abstract}
Penelitian ini dilaksanakan pada Pegawai Biro Administasi Umum Universitas Islam Negeri (UIN) Sultan Syarif Kasim Riau yang berkedudukan di Gedung Rektorat UIN Sultan Syarif Kasim Riau JL.H.R. Subrantas No. 155 Tampan-Pekanbaru, yang berlangsung dari bulan Januari sampai dengan Maret 2009.

Penelitian ini bertujuan untuk mengetahui pengaruh insentif dan lingkungan kerja terhadap semangat kerja pegawai pada Biro Administrasi Umum UIN Sultan Syarif Kasim Riau dan untuk mengetahui faktor yang paling dominan yang mempengaruhi semangat kerja pegawai. Perumusan masalah yang penulis kemukakan dalam penelitian ini adalah bagaimanakah insentif dan lingkungan kerja mempengaruhi semangat kerja pegawai Biro Administrasi Umum UIN Sultan Syarif Kasim Riau dan manakah faktor yang paling dominan mempengaruhi semangat kerja pegawai pada Biro Administrasi Umum UIN Sultan Syarif Kasim Riau.

Hipotesis yang penulis kemukakan pada penelitian ini adalah: diduga insentif dan lingkungan kerja berpengaruh secara signifikan terhadap semangat kerja pegawai pada Biro Administasi Umum UIN Sultan Syarif Kasim Riau dan faktor yang paling dominan mempengaruhi semangat kerja pegawai pada Biro Administrasi Umum UIN Sultan Syarif Kasim Riau adalah faktor insentif. Populasi dalam penelitian ini adalah Pegawai pada Biro Administrasi Umum UIN Sultan Syarif Kasim Riau dengan jumlah sampel adalah 54 orang responden.

Variabel-variabel yang diteliti dalam penelitian ini terdiri dari variabel bebas dan variabel terikat. Adapun variabel bebas terdiri dari insentif $\left(X_{1}\right)$ dan lingkungan kerja $\left(X_{2}\right)$ sedangkan variabel terikat adalah semangat kerja (Y).

Secara bersama-sama, insentif $\left(\mathrm{X}_{1}\right)$ dan lingkungan kerja $\left(\mathrm{X}_{2}\right)$ berpengaruh terhadap semangat kerja (Y). Terbukti dari hasil perhitungan F-hitung $=40,107$ lebih besar dari F-tabel $=3,17$ dengan tingkat signifikan 0,000 . Hasil pengujian secara parsial diperoleh t-hitung masing-masing variabel $\mathrm{X}_{1}=8,861$ dan $\mathrm{X}_{2}=2,578$ yang lebih besar dari t-tabel $=1,6752$, hal ini menunjukkan bahwa masing-masing variabel bebas secara parsial berpengaruh secara positif dan signifikan terhadap semangat kerja pegawai pada Biro Administrasi Umum UIN Sultan Syarif Kasim Riau. Nilai t-hitung variabel $\mathrm{X}_{1}$ lebih besar dari $\mathrm{X}_{2}$ menunjukkan bahwa faktor insentif mempunyai pengaruh lebih dominan dibandingkan faktor lingkungan kerja.
\end{abstract}

Keywords: Insentif, Semangat Kerja, Lingkungan kerja

Email Address: suparjono@gmail.com 


\section{Pendahuluan}

Seiring dengan dilaksanakannya reformasi birokrasi oleh pemerintah, maka pada saat ini pemerintah menuntut kinerja yang lebih baik dari Pegawai Negeri Sipil (PNS). Tujuan akhir dari usaha-usaha Pemerintah tersebut tentunya adalah untuk memperbaiki pelayanan publik yang lebih baik kepada masyarakat.

Pegawai atau karyawan adalah salah satu aset utama yang dimiliki oleh organisasi/perusahaan dimana peranannya cukup signifikan didalam mendukung pencapaian tujuan-tujuan organisasi. Hal ini disebabkan Pegawai adalah sebagai subjek atau pelaku dari kegiatan-kegiatan yang dilakukan oleh sebuah organisasi, sehingga reformasi birokrasi akan sukses apabila seluruh pegawai mendukung dengan menunjukkan kinerja yang baik dan selalu bersemangat didalam bekerja.

Semangat kerja adalah kemampuan sekelompok orang untuk bekerjasama dengan giat dan konsekuen dalam mengejar tujuan bersama. Sebuah pekerjaan dapat diselesaikan dengan baik dan tepat waktu dapat terwujud apabila didalam pelaksanaannya terdapat semangat kerja yang tinggi dari para pegawai. Insentif dan lingkungan kerja adalah termasuk faktor-faktor yang dapat mempengaruhi semangat kerja pegawai.

Untuk menghadapai tantangan kerja yang semakin berat tentunya dibutuhkan motivasi agar pegawai mampu bekerja dengan baik. Salah satunya dengan pemberian insentif yang besarannya proporsional dan juga bersifat progresif yang artinya sesuai dengan jenjang karir, karena insentif sangat diperlukan untuk memicu semangat kerja pegawai yang pada akhirnya akan meningkatkan kinerja pegawai.

Selain insentif, faktor lain yang dapat mempengaruhi semangat kerja pegawai adalah lingkungan kerja.
Pengertian lingkungan kerja adalah segala sesuatu yang ada disekitar para pekerja dan dapat mempengaruhi dirinya dalam menyelesaikan semua tugas yang diberikan kepadanya. Apabila sebuah lingkungan kerja itu tidak nyaman seperti bau, bising, tentunya hal tersebut akan membuat para pegawai tidak konsentrasi didalam bekerja, bahkan juga akan menyebabkan tidak tercapainya kinerja yang diharapkan.

Indikasi tidak adanya semangat kerja pegawai pada Biro Administrasi Umum UIN Sultan Syarif Kasim Riau dapat dilihat dari tingginya absensi ketidakhadiran (alpa). Selain dari data absensi, tidak adanya semangat kerja pegawai juga dapat hal-hal sebagai berikut:

1. Banyaknya pegawai yang tidak berada ditempat pada saat jam pelayanan, sehingga sering mengecewakan orang-orang yang akan diberikan layanan.

2. Penyelesaian pekerjaan yang terlambat, karena tidak optimalnya pemanfaatan waktu jam kerja dimana pegawai banyak yang mengobrol atau melakukan pekerjaan yang lain.

3. Sering terlambatnya pegawai masuk kantor dan pulang lebih awal dari waktu yang ditentukan.

\section{Rumusan Masalah}

(1). Bagaimanakah insentif dan lingkungan kerja mempengaruhi semangat kerja pegawai pada Biro Administrasi Umum Universitas Islam Negeri (UIN) Sultan Syarif Kasim Riau?

(2). Faktor manakah yang paling dominan diantara insentif dan lingkungan kerja didalam mempengaruhi semangat kerja pegawai pada Biro Administasi 
Umum Universitas Islam Negeri (UIN) Sultan Syarif Kasim Riau?

\section{Tujuan Penelitian}

(1). Untuk menganalisis pengaruh insentif dan lingkungan kerja terhadap semangat kerja pegawai pada Biro Administrasi Umum Universitas Islam Negeri (UIN) Sultan Syarif Kasim Riau.

(2). Untuk mengetahui faktor yang paling dominan diantara insentif dan lingkungan kerja didalam mempengaruhi semangat kerja pegawai pada Biro Administrasi Umum Universitas Islam Negeri (UIN) Sultan Syarif Kasim Riau.

\section{Kegunaan Penelitian}

(1). Peneliti dapat lebih memahami dan dapat mengaplikasikan ilmu manajemen sumber daya manusia pada Universitas Islam Negeri (UIN) Sultan Syarif Kasim Riau, khususnya dalam meningkatkan semangat kerja pegawai

(2). Secara praktis hasil penelitian ini diharapkan dijadikan sebagai bahan pertimbangan bagi pimpinan pada Universitas Islam Negeri (UIN) Sultan Syarif Kasim Riau sebagai pembuat kebijakan dan pengambil keputusan dalam rangka meningkatkan semangat kerja pegawai.

(3). Secara teoritis hasil penelitian ini menguji aplikasi teori, manajemen sumber daya manusia yang berkaitan semangat kerja pegawai dilingkungan Perguruan Tinggi Agama Islam Negeri (PTAIN).

\section{Tinjauan Pustaka}

\section{Insentif}

Insentif sebagai sarana motivasi yang mendorong para pegawai untuk bekerja dengan kemampuan yang optimal, yang dimaksudkan dengan pendapatan ekstra diluar gaji atau upah yang telah ditentukan. Pemberian insentif dimaksudkan agar dapat memenuhi kebutuhan para pegawai dan keluarga mereka. Istilah sistem insentif pada umumnya digunakan untuk menggambarkan rencana-rencana pembayaran upah yang dikaitkan secara langsung atau tidak langsung dengan berbagai standar kinerja pegawai atau profitabilitas organisasi.

Kompensasi dan insentif mempunyai hubungan yang erat, dimana insentif merupakan komponen dari kompensasi dan keduanya sangat menentukan dalam pencapaian tujuan dan sasaran organisasi secara keseluruhan. Insentif dapat dirumuskan sebagai balas jasa yang memadai kepada para pegawai yang prestasinya melebihi standar yang telah ditetapkan. Insentif merupakan faktor pendorong bagi pegawai untuk bekerja lebih baik agar kinerja pegawai dapat meningkat.

Menurut Malayu S.P. Hasibuan (2001:117) mengemukakan bahwa insentif adalah tambahan balas jasa yang diberikan kepada karyawan tertentu yang prestasinya diatas prestasi standar. Sedangkan menurut Anwar Prabu Mangkunegara (2002:89) mengatakan bahwa insentif adalah suatu bentuk motivasi yang dinyatakan dalam bentuk uang atas dasar kinerja yang tinggi dan juga merupakan rasa pengakuan dari pihak organisasi terhadap kinerja karyawan dan kontribusi terhadap organisasi (instansi).

\section{Menurut T. Hani Handoko} (2002:77) mengemukakan bahwa insentif merupakan perangsang yang ditawarkan kepada para karyawan untuk melaksanakan kerja sesuai atau lebih 
tinggi dari standar-standar yang telah ditetapkan.

Jadi menurut pendapat-pendapat para ahli diatas dapat penulis simpulkan, bahwa insentif adalah dorongan pada seseorang agar mau bekerja dengan baik dan agar lebih dapat mencapai tingkat kinerja yang lebih tinggi sehingga dapat membangkitkan semangat kerja dan motivasi seorang pegawai. Dimana pada prinsipnya insentif menguntungkan kedua belah pihak. Organisasi mengharapkan adanya kekuatan dan semangat yang timbul dalam diri penerima insentif yang mendorong mereka untuk bekerja dengan baik dalam arti lebih produktif agar tujuan yang ingin dicapai oleh instansi dapat terpenuhi sedangkan bagi para pegawai sebagai salah satu alat pemuas kebutuhannya.

\section{Jenis-jenis Insentif}

Pemberian insentif sebagai alat motivasi pada akhirnya akan berdampak kepada semangat kerja pegawai merupakan usaha dari pimpinan untuk menggerakkan dan mengerahkan kinerja pegawai semaksimal mungkin dalam pencapaian tujuan yang telah ditetapkan. Menurut Malayu S.P. Hasibuan (1996:99) insentif terdiri dari :

a. Material Insentif

Adalah alat motivasi yang diberikan berupa uang atau barang yang mempunyai nilai pasar, memberikan kebutuhan yang bersifat ekonomis.

b. Non Material Insentif

Adalah alat motivasi yang diberikan berupa barang-barang atau benda yang tak ternilai hanya memberikan kepuasan atau kebanggan rohani saja.

c. Kombinasi Material dan Non Material Adalah alat motivasi yang diberikan itu berupa material (uang atau barang) dan non material (medali dan piagam penghargaan).

\section{Lingkungan Kerja}

Menurut Alex S. Nitisemito (1996:193) lingkungan kerja adalah segala sesuatu yang ada disekitar para pekerja dan dapat mempengaruhi dirinya dalam menyelesaikan semua tugas yang diberikan kepadanya.

Lingkungan kerja merupakan keseluruhan alat perkakas yang dihadapi, lingkungan sekitarnya dimana seorang bekerja, metode kerjanya serta pengaturan kerjanya baik sebagai perorangan maupun sebagai kelompok (Sedarmayanti, 1996:5)

Kondisi lingkungan kerja yang tidak baik, baik dari segi fasilitas fisik maupun dari letak lokasi tempat kerja akan menimpulkan ketidakpuasan karyawan serta tingkat absensi dan labour turn over meningkat (Simamora, 1995:6).

Menurut Gerry Dessler (1998:311) kodisi kerja yang tidak aman merupakan alasan utama penyebab kecelakaan, dimana kondisi tersebut adalah peralatan perlindungan yang kurang memadai, peralatan rusak, gedung yang sumpek, penerangan yang tidak memadai, ventilasi yang tidak memadai, tidak cukupnya penggantian udara dan suara bising yang dapat merusak pendengaran.

Kondisi fisik tempat kerja mempengaruhi semangat kerja karyawan, buruknya kondisi fisik tempat kerja akan sangat mempengaruhi semangat kerja karyawan, kondisi fisik tempat kerja yang dimaksud adalah suasana tempat kerja para karyawan melaksanakan pekerjaannya (Kusriyanto, 1995:122). Menurut Edwin B. Filippo (1995: 6) ada beberapa faktor yang dapat mempengaruhi lingkungan kerja yang baik:
a. Pewarnaan
Pewarnaan yang baik adakan 
mempengaruhi jiwa tenaga kerja, untuk itu setiap organisasi harus dapat menentukan komposisi yang serasi sehingga akan dapat menimbulkan perasaan yang menyenangkan.

b. Kebersihan

Kebersihan akan dapat pula menciptakan lingkungan kerja yang sehat bagi diri pegawai, apabila lingkungan kerja bersih, maka hal ini akan dapat menimbulkan perasaan yang menyenangkan.

c. Pertukaran Udara

Pertukaran udara yang baik akan dapat mempengaruhi kesegaran fisik dari para pegawai, sedangkan pertukaran udara yang kurang baik akan mengganggu keseharan dan dapat pula menimbulkan kelelahan yang cepat.

d. Penerangan

Penerangan yang baik dipengaruhi oleh kecerahan, pengarahan, ratanya penyebaran warna. Melalui penerangan yang baik akan mempengaruhi produktivitas kerja.

e. Musik

Musik yang mengalun akan dapat mempengaruhi suasana kejiwaan, yakni akan dapat menimbulkan suasana gembira apalagi pada waktu istirahat sehingga dapat pula mengurangi perasaan lelah dan dapat menimbulkan semangat dan kegairahan kerja untuk bekerja kembali.

f. Bau

Bau merupakan faktor yang mempengaruhi produktifitas pekerja dimana jika lingkungan kerja yang terlalu bau akan dapat menimbulkan perasaan bosan sehingga akan berpengaruh terhadap hasil kerja yang mereka lakukan.

g. Keamanan

Perlindungan yang diberikan pada tenaga kerja yang menggunakan alatalat kerja tertentu yang dapat menimbulkan kemungkinan akan kecelakaan yang terjadi adalah hal yang harus diperhatikan. Rasa aman dan tentram akan lebih diutamakan dari pada efisiensi pekerjaan itu sendiri, jika dilihat dari sudut pandang pekerja.

h. Kebisingan

Kebisingan yang terjadi akan dapat mengganggu konsentrasi terhadap pekerjaan tertentu, terutama pekerjaan yang memerlukan pemusatan pikiran, sehingga hal iniakan sering menimbulkan kesalahan pekerjaan.

\section{Semangat Kerja}

Semangat (jiwa) pada sebuah kelompok merupakan sesuatu yang sangat dibutuhkan didalam sebuah organisasi. Menurut Tohardi (2002:427) semangat kerja adalah kemampuan sekelompok orang-orang untuk bekerjasama dengan giat dan konsekuen dalam mengejar tujuan bersama.

Sedangkan menurut Hadi (1998:160) semangat kerja adalah sifat kejiwaan yang erat hubungannya dengan faktor kepuasan kerja, kegairahan kerja, dan keinginan untuk mempertimbangkan hasil kerja.

Apabila pekerja merasa senang, optimis, mengenai kegiatan-kegiatan dan tugas kelompok serta ramah satu sama lain, maka mereka dikatakan memiliki semangat kerja yang tinggi. Tetapi apabila mereka tampak tidak puas, lekas marah, suka membantah, gelisah, dan suka pesimis, maka dapat dikatakan adanya semangat kerja yang rendah 
(Moekijat, 1999:15).

Semangat kerja karyawan erat kaitannya dengan sikap mereka terhadap pekerjaan, terhadap kelompoknya, dan juga terhadap manajemennya. Untuk itu dalam membahas semangat kerja pegawai harus dilihat dari berbagai aspek dan keperluan karyawan. Semangat kerja yang baik dapat diketahui dari berbagai segi berikut (Wursanto, 1998:150):

a. Disiplin kerja yang tinggi

b. Antusias kerja

c. Hubungan kerja yang harmonis

d. Loyalitas yang tinggi dari karyawan

e. Terpenuhinya kebutuhan fisik ataupun kebutuhan psikologis

f. Kreatifitas dan Inisiatif yang tinggi

\section{Kerangka Pemikiran}

Berdasarkan teori dan hasil riset terdahulu yang dikemukakan diatas maka penulis dapat merumuskan kerangka pemikiran bahwa alur pemikiran dalam penulisan ini yaitu dimulai dengan mengidentifikasi pengertian . Menurut pendapat dari Nitisemito (1999:109) Insentif dan lingkungan kerja adalah termasuk kedalam faktor-faktor yang mempengaruhi semangat kerja, oleh karena itu sudah seharusnya seorang pimpinan memberikan perhatian terhadap masalah insentif dan lingkungan kerja di organisasi yang dipimpinnya, karena hal tersebut dapat mempengaruhi semangat kerja pegawai.

\section{Hipotesis}

(1). Diduga faktor insentif dan lingkungan kerja mempengaruhi secara signifikan terhadap semangat kerja pegawai pada Biro Administrasi Umum Universitas Islam Negeri (UIN) Sultan Syarif Kasim Riau.

(2). Diduga faktor insentif lebih dominan mempengaruhi semangat kerja pegawai pada Biro Administrasi Umum Universitas Islam Negeri (UIN) Sultan Syarif Kasim Riau?

\section{Metodologi Penelitian}

Penelitian ini menggunakan menggunakan metode deskriptif analisis dimana penelitian mengambil seluruh populasi sebagai sampel. Dan pengumpulan data melalui kuesioner. Setelah data diperoleh kemudian hasilnya disajikan secara deskriptif dan pada akhir penelitian akan dianalisis untuk menguji hipotesis yang diajukan pada awal penelitian ini.

\section{Populasi Dan Sampel}

Populasi dalam penelitian ini adalah seluruh pegawai pada Biro Administrasi Umum Kantor Rektorat Universitas Islam Negeri (UIN) Sultan Syarif Kasim Riau yang berjumlah 117 orang. Untuk mendapatkan sampel yang dapat menggambarkan dan mencandrakan populasi, maka dalam penentuan sampel penelitian ini digunakan rumus Slovin (Umar, 2004:108).

Teknik sampling yang digunakan dalam penelitian ini adalah dengan menggunakan prosedur stratified sampling yakni proses pengambilan sampel pemilihan sampel dengan cara stratified atau dibentuk strata tingkatan atau kelompok (Istijanto, 2006:116). Sehingga dari total populasi sebanyak 117 orang diambil sampel sebanyak 54 orang.

\section{Jenis dan Teknik Pengumpulan Data}

Jenis data dalam penelitian ini adalah data primer dan data sekunder. Data primer diperoleh dengan penyebaran kuesioner dan pengamatan langsung oleh penulis, Sedangkan data sekunder 
diperoleh dengan meminjam arsip-arsip atau dokumen-dokumen kepegawaian.

\section{Teknik Analisa Data}

Analisis data dimaksudkan untuk mengkaji dan mengetahui hubungan antar variabel bebas pertama $\left(\mathrm{X}_{1}\right)$ yakni insentif, variabel bebas kedua $\left(\mathrm{X}_{2}\right)$ lingkungan kerja serta variabel terikat (Y) yakni semangat kerja pegawai pada Universitas Islam Negeri (UIN) Sultan Syarif Kasim Riau. Pada penelitian ini penulis menggunakan metode analisis regresi linier berganda dengan persamaan sebagai berikut:

Dengan Persamaan sebagai berikut:

Model Regresi I : $\mathbf{Y}=\boldsymbol{\beta}_{0}+\boldsymbol{\beta}_{1} \mathbf{X}_{1}+\boldsymbol{\beta}_{2} \mathbf{X}_{2}+\varepsilon_{\mathrm{i}}$

$\begin{array}{ll}\text { Keterangan: } \\ \mathrm{Y} & : \text { Variabel Semangat Kerja } \\ \mathrm{X}_{1} & \text { : Variabel Insentif } \\ \beta_{0} & : \text { Konstanta } \\ \beta_{1} \text { dan } \beta_{2} & : \text { Koefisien regresi linier } \\ & \text { berganda } \\ \boldsymbol{\varepsilon}_{\mathbf{i}} & : \text { Error/Kesalahan } \\ \beta_{0} & : \text { Nilai } \mathrm{Y}, \text { apabila } \mathrm{X}_{1} \text { dan } \\ & \mathrm{X}_{2}=0 \\ \beta_{1} & \text { Besarnya kenaikan/ } \\ & \text { Penurunan } \mathrm{Y} \text { dalam satuan, } \\ & \text { Jika } \mathrm{X}_{1} \text { naik/turun satu } \\ & \text { satuan dan } \mathrm{X}_{2} \text { konstan } \\ & \text { Besarnya kenaikan/ } \\ \beta_{2} & \text { Penurunan } \mathrm{Y} \text { dalam satuan, } \\ & \text { Jika } \mathrm{X}_{2} \text { naik/turun satu } \\ & \text { satuan dan } \mathrm{X}_{1} \text { konstan }\end{array}$

\section{Hasil dan Pembahasan}

\section{Pembuktian Hipotesis Secara Simultan (Uji-F)}

Pembuktian hipotesis secara simultan digunakan untuk melihat pengaruh variabel bebas secara bersamasama yaitu insentif dan lingkungan kerja terhadap variabel terikatnya dalam hal ini adalah semangat kerja pegawai. Berdasarkan hasil perhitungan melalui komputer dengan menggunakan aplikasi SPSS for windows versi 15 diperoleh model persamaan regresi linier berganda sebagai berikut:

$Y=1,436+0,385 X_{1}+0,208 X_{2}$

Persamaan regresi linier berganda diatas menunjukkan bahwa:

1. Nilai $\beta_{0}=1,436$ merupakan konstanta yang apabila nilai seluruh variabel dianggap nol, maka nilai pengaruh semangat kerja pegawai (Y) sebesar 1,473 satuan.

2. Koefisien regresi variabel insentif $\left(X_{1}\right)$ $=0,385$ ini menunjukkan besarnya pengaruh variabel insentif terhadap semangat kerja kerja pegawai. Tanda positif menunjukkan koefisien arah hubungan yang positif. Artinya dengan adanya kenaikan satu satuan variabel insentif maka semangat kerja pegawai akan naik sebesar 0,385 kali dengan anggapan faktor yang lain konstan (cateris paribus).

3. Koefisien regresi variabel lingkungan kerja $\left(X_{2}\right)=0,208$ ini menunjukkan besarnya pengaruh variabel lingkungan kerja terhadap semangat kerja pegawai. Tanda positif menunjukkan koefisien arah hubungan yang positif. Artinya dengan adanya kenaikan satu satuan variabel lingkungan kerja maka semangat kerja pegawai akan naik sebesar 0,208 kali dengan anggarapan faktor yang lain konstan (cateris paribus).

Berdasarkan hasil perhitungan melalui komputer dengan menggunakan aplikasi SPSS for windows versi 15 juga diperoleh angka koefisien determinasi berganda ( $\mathrm{R}$ square) yang diperoleh dari 
kelipatan (R) adalah sebesar 0,611 menunjukkan bahwa $61,1 \%$ semangat kerja pegawai (Y) bisa diterangkan dengan variabel insentif $\left(\mathrm{X}_{1}\right)$ dan lingkungan kerja $\left(\mathrm{X}_{2}\right)$ sedangkan sisa nya $(100 \%-61,1 \%=38,9 \%)$ dapat diterangkan oleh variabel lain yang tidak diteliti pada penelitian ini.

Untuk membuktikan hipotesis secara keseluruhan apakah semua variabel bebas secara bersama-sama mempunyai pengaruh terhadap variabel terikat maka digunakan uji-F, dengan ketentuan:

- Jika F hitung > F tabel maka terdapat hubungan/pengaruh antara variabel bebas dengan variabel terikat.

- Jika F hitung < F tabel maka tidak terdapat hubungan/pengaruh antara variabel bebas dengan variabel terikat

Dengan demikian hipotesis yang menyatakan bahwa faktor insentif dan lingkungan kerja mempunyai pengaruh yang signifikan terhadap semangat kerja pegawai pada Biro Administrasi Umum UIN Sultan Syarif Kasim Riau dapat diterima. Hal ini terbukti nilai $\mathrm{F}$ hitung lebih besar dari $\mathrm{F}$ tabel.

Dari perhitungan aplikasi SPSS diperoleh $F$ hitung diperoleh sebesar 40,107 dan dengan tingkat signifikan sebesar 0,000 sedangkan $F$ tabel dengan tingkat signifikan $\quad \alpha 0,05=3,17$. Jadi dapat disimpulkan bahwa $\mathrm{F}$ hitung lebih besar dari F tabel $(40,107>3,17)$.

\section{Pembuktian Hipotesis Secara Parsial (Uji-t)}

Untuk membuktikan hipotesis secara parsial digunakan uji-t yaitu untuk mengetahui besarnya pengaruh masingmasing variabel bebas secara parsial atau sendiri-sendiri dalam menjelaskan variabel terikatnya sehingga diketahui variabel bebas mana yang paling dominan mempengaruhi variabel terikat yaitu semangat kerja pegawai dari kedua variabel bebas yang diteliti dalam penelitian ini.

Maka berdasarkan kepada hasil perhitungan program SPSS versi 15 diperoleh besarnya nilai koefisien regresi secara parsial dari masing variabel bebas yang diteliti.

1. Untuk variabel $X_{1}$ diperoleh nilai $t-$ tabel $=1,6752$, nilai t-hitung $=8,861$ dengan tingkat signifikan 0,000 .

2. Untuk variabel $X_{1}$ diperoleh nilai $t-$ tabel=1,6752, nilai t-hitung $=2,578$ dengan tingkat signifikan 0,013

Uji $t$ dilakukan dengan membandingkan t-hitung dengan t-tabel pada signifikan $\alpha=0,05 \%$ dan dengan derajad kebebasan (degree of freedom) df $=\mathrm{n}-\mathrm{k}$ yaitu $1=54-2-1=51$.

Pada t-tabel diperoleh diperoleh $\mathrm{t}$ nya adalah sebesar 1,6752. Hasil pengujian dari masing-masing variabel bebas tersebut adalah:

1. Variabel $X_{1}$ (Insentif) 8,861>1,6752, maka dapat disimpulkan bahwa variabel $\mathrm{X}_{1}$ berpengaruh terhadap semangat kerja pegawai (dengan signifikan sebesar 0,000).

2. Variabel $X_{2}$ (lingkungan kerja) 2,578>1,6752, maka dapat disimpulkan bahwa variabel $\mathrm{X}_{2}$ berpengaruh terhadap semangat kerja pegawai (dengan signifikan sebesar 0,013).

Dari penjelasan diatas maka dapat disimpulkan bawa kedua variabel diatas yaitu Variabel $\mathrm{X}_{1}$ dan variabel lingkungan kerja $\left(\mathrm{X}_{2}\right)$ benar-benar berpengaruh secara signifikan terhadap 
semangat kerja pegawai, karena thitung dari kedua variabel tersebut lebih besar dari t-tabelnya.

Selanjutnya dari kedua variabel bebas yang diteliti, Variabel $\mathrm{X}_{1}$ (insentif) mempunyai pengaruh yang paling dominan, hal ini dibuktikan dengan sebesar 8,861 dalam menerangkan variabel terikatnya (Y) yaitu semangat kerja pegawai karena memiliki nilai t-hitung yang lebih besar dibandingkan variabel $\mathrm{X}_{2}$ (lingkungan kerja) sebesar 2,578.

\section{Kesimpulan}

\section{Kesimpulan}

(1). Berdasarkan hasil analisis yang telah dilakukan, maka telah terbukti bahwa variabel Insentif dan Lingkungan Kerja secara simultan/ bersama-sama mempunyai hubungan dan pengaruh yang signifikan terhadapat Semangat Kerja Pegawai pada Biro Administrasi Umum UIN Sultan Syarif Kasim Riau.

Berdasarkan tanggapan responden tentang Variabel pertama yaitu Insentif, responden merasa insentif yang mereka terima belum memadai bagi para pegawai, Insentif yang diberikan tidak sesuai dengan tanggung jawab dan prestasi kerja yang dicapai oleh para pegawai, pemberian insentif tidak tepat waktu serta tidak adanya kepuasan kerja pegawai atas pemberitan insentif, sehingga insentif yang telah diberikan selama ini belum mampu meningkatkan semangat dan kegairahan kerja pegawai.

(2). Variabel kedua yang mempengaruhi semangat kerja pegawai pada Biro Administrasi Umum UIN Sultan
Syarif Kasim Riau adalah lingkungan kerja. Berdasarkan hasil tanggapan responden tentang lingkungan kerja, diperoleh hasil bahwa responden merasa lingkungan kerja pada Biro Administrasi Umum UIN Sultan Syarif Kasim Riau masih kurang nyaman, kondisi keamanan masih kurang memadai, sehinggal lingkungan kerja yang dirasakan pada saat ini belum mampu memberikan semangat kerja yang maksimal.

\section{Saran}

Adapun saran-saran yang penulis kemukakan kepada Para Pimpinan UIN Sultan Syarif Kasim Riau terkait penelitian berkaitan dengan variabel Insentif, Lingkungan Kerja dan Semangat Kerja adalah sebagai berikut:

1. Dalam rangka meningkatkan semangat kerja pegawai, diharapkan kepada Pimpinan/Pembuat kebijakan pada UIN Sultan Syarif Kasim Riau memperhatikan dan memahami bahwa faktor insentif dan lingkungan kerja dapat mempengaruhi semangat kerja pegawai. Misalnya dengan melakukan evaluasi terhadap hal-hal yang berkaitan dengan semangat kerja pegawai secara berkala khususnya berkaitan dengan faktor insentif dan lingkungan kerja.

2. Hal yang tidak kalah pentingnya adalah perlunya pimpinan pimpinan UIN Sultan Syarif Kasim Riau agar selalu menciptakan suasana kerja yang kondusif dan hormonis dimana didalamnya tercipta hubungan kerja yang baik antara sesama pegawai serta antara pegawai dengan atasan. 


\section{Daftar Pustaka}

Danim, Sudarman. 2004. Motivasi Kepemimpinan dan Efektifitas Kelompok. Rineka Cipta, jakarta

Dessler,Gary.1998. Manajemen Sumber Daya Manusia. Edisi Bahasa Indonesia, PT. Prenhallindo. Jakarta

Filippo,Edwin.B, 1995. Personel Manajemen. Jilid kedua, Edisi Keenam, Cetakan Keempat, Jakarta

Freemont,.E Kast dan James .E Rosenzweig, Handoko, T. Hani. 1998. Organisasi dan Manajemen. Bumi Aksara, Jakarta

Gomes, Faustin Cardoso. 2000. Manajemen Sumber Daya Manusia. Andi Offset, Yogyakarta

Hadi, Sutrisno.1998. Bagaimana Memimpin dan Mengawasi Pegawai Saudara. Jaya Sakti, Jakarta

Handoko, T. Hani. 2002. Manajemen Personalia dan Sumber Daya Manusia, BPFE UGM, Yogyakarta

Hasibuan, Malayu.S.P. 2001. Manajemen Sumber Daya Manusia. Bumi Aksara, Jakarta

Istijanto. 2006. Riset Sumber Daya Manusia. Gramedia Pustaka Utama, Jakarta

Koontz, Harold., Cyreill O' Donel dan Heinz Weihrich, Manajemen Terjemahan Antarikso. Erlangga, Jakarta

Kusnoto, Hendra. 2001. The World's Best Management Practice. Gramedia
Pustaka, Jakarta

Kusriyanto, Bambang. 1995. Meningkatkan Produktivitas Karyawan. PT. Binaman Pressindo, Jakarta

Mangkunegara, A. Anwar Prabu. 2002. Manajemen Sumber Daya Manusia Perusahaan, PT. Remaja Rosda Karya, Bandung

Moekijat. 1999. Manajemen Tenaga Kerja dan Hubungan Tenaga Kerja. Pioner Jaya, Jakarta

Nitisemito, Alex S. 1996. Manajemen Personalia, Ghalia Indonesia, Jakarta

Rivai, Veithzal. 2005. Manajemen Sumber Daya Manusia Untuk Perusahaan. Murai Kencana, Jakarta

Robbin, Stehpen. 2003. Prilaku Organisasi. PT. Prenhallindo, Jakarta

Sedarmayanti. 1996. Tata Kerja dan Produktivitas. Mandar Maju, Bandung

Siagian, Sondang P. Manajemen Sumber Daya Manusia. Bumi Aksara, Jakarta

Simamora, Henry. 1995. Manajemen Sumber Daya Manusia. STIE YKPN, Yogyakarta

Sudjana. 1991. Metode Statistik. Edisi Kelima, Tarsito, Bandung

Sugiyono, 1999. Metode Penelitian Bisnis. Alfabeta, Bandung

Sutanto, Eddy Madiono dan Setiawan, Budhi. Dalam Jurnal Manajemen 
Jurnal Bahtera Inovasi Vol. 3 No. 2 Tahun 2020

@Program Studi Manajemen

FE Universitas Maritim Raja Ali Haji

dan Kewirausahaan, Vol. 2 No. 2, Edisi September 2000, diterbitkan oleh Fakultas Ekonomi Universitas Kristen Petra

Tohardi, Ahmad. 2002. Pemahaman Praktis Manajemen Sumber Daya Manusia. CV. Mandar Maju, Bandung

Umar, Husein. 2004. Metode Penelitian Untuk Skripsi dan Tesis Bisnis. PT.
Raja Grafindo, Jakarta

Wursanto. $1998 . \quad$ Dasar-Dasar Manajemen, Pustaka Dian, Jakarta

Widawati, Anik Sri.dalam Jurnal Ilmiah Perusahaan, Vol. 2 No. 2, Edisi September 2006, Diterbitkan Oleh STMIK AMIKOM 